\title{
Energy Integration in South America Region and the Energy Sustainability of the Nations
}

\author{
Miguel Edgar Morales Udaeta, Antonio Gomes dos Reis, José Aquiles Baesso Grimoni, \\ Antonio Celso de Abreu Junior \\ GEPEA/EPUSP, Energy Group of the Department of the Electrical Energy and Automation Engineering/ \\ Polytechnic School of the University of São Paulo, São Paulo, Brazil \\ Email: udaeta@pea.usp.br
}

Received 22 January 2015; accepted 29 April 2015; published 5 May 2015

Copyright (C) 2015 by authors and Scientific Research Publishing Inc.

This work is licensed under the Creative Commons Attribution International License (CC BY).

http://creativecommons.org/licenses/by/4.0/

(c) (i) Open Access

\begin{abstract}
The objective of this manuscript is to analyze relation involving the energy sector and socioeconomic growth and, then, contextualize the process of energy integration within the development policies in South America. The methodology considers data related to the world's economy and energy consumption and energy integration policy in countries and regions; and, South America's energy potential and the energy integration process. Results show that despite the political and institutional difficulties involving the process, energy integration can bring a lot of benefits for countries development. The process of energy integration in South America is divided in three moments, but in both periods the transnational energy projects were restricted, mostly, by a bilateral plan and the creation of physical links in a region. In the 21th century's context, it should be noted Brazil's participation which has been consolidated as a lead country in this process, and, also the IIRSA (Initiative for the Integration of Regional Infrastructure in South America, nowadays renamed as COSIPLAN) like the main initiative in energy integration in the continent, in a context where the projects are no longer limited to traditional economic blocs. Finally, we note a lack of consensus in defining a comprehensive model of integration and solving asymmetries both within countries and between them.
\end{abstract}

\section{Keywords}

Energy Integration, Energy Planning, Energy Resources, Regional Geo-Energy, South America, Energy Policy, Development

\section{Introduction}

Despite the economic integration process arising in Europe (including the energy integration), the related dis-

How to cite this paper: Udaeta, M.E.M., Reis, A.G., Grimoni, J.A.B. and Abreu Junior, A.C. (2015) Energy Integration in South America Region and the Energy Sustainability of the Nations. Energy and Power Engineering, 7, 161-173.

http://dx.doi.org/10.4236/epe.2015.75016 
cussions soon spread worldwide, leading initiatives in other regions, including South America. From the second half of the 20th century, some economic integration mechanisms have been developed in the South-American region such as the creation of the Andean Community of Nations (CAN), the Southern Common Market (Mercosur) and the Union of South American Nations (UNASUR), plus some bilateral initiatives geared to the use of shared energy resources or trade them.

In this last, century has noticed a significant increase in the number of energy projects in South America, largely associated with the Initiative for the Integration of Regional Infrastructure in South America (IIRSA), the resulting economic growth in the region and, thus, the increase of demand energy. Indeed, studies of the International Energy Agency [1] and the World Energy Council [2], show that the energy demand of developing countries has increased significantly—due to the considerable growth of their economies—a phenomenon which also includes America South and specifically Brazil, which in 2011 occupied the 6th position in the world ranking of Gross Domestic Product (GDP) [3] and was seventh country to consume more energy in the world [4].

\section{Energy and Development}

The availability of energy is necessary for human development throughout history base, so that the use of different energy sources is the thread of history man stuff having made possible the two major changes in their relationship with nature: Neolithic Revolution and the Industrial Revolution [5].

In fact, when looking at Figure 1, below, one sees that the energy needs of society monitor the evolution and development of mankind. From an energy consumption of about 2000 kcal per day, which characterized the primitive man, energy consumption increased by 1 million years to 230,000 kcal per day, taking into account the consumption pattern of the so-called technological man [6].

The invention of the steam engine (a mark of the Industrial Revolution, which started in the 18th century in England) created the technical basis for the development of new forms and sources of exploitation and use of energy, replacing human labor with machines and subsequently developing means of transport [7]. By enabling the large-scale production and fast shipping of goods, the Industrial Revolution spurred the development of capitalism, specifically the economic development of industrialized nations. Moreover, this process resulted in the gradual increase in world energy demand (especially in developed countries) and, thus, for new sources and ways to harness and convert energy. This historical process shows a dialectical relationship between energy and development, in which the ability to use and power is at the same time, therefore the level of technical and eco-

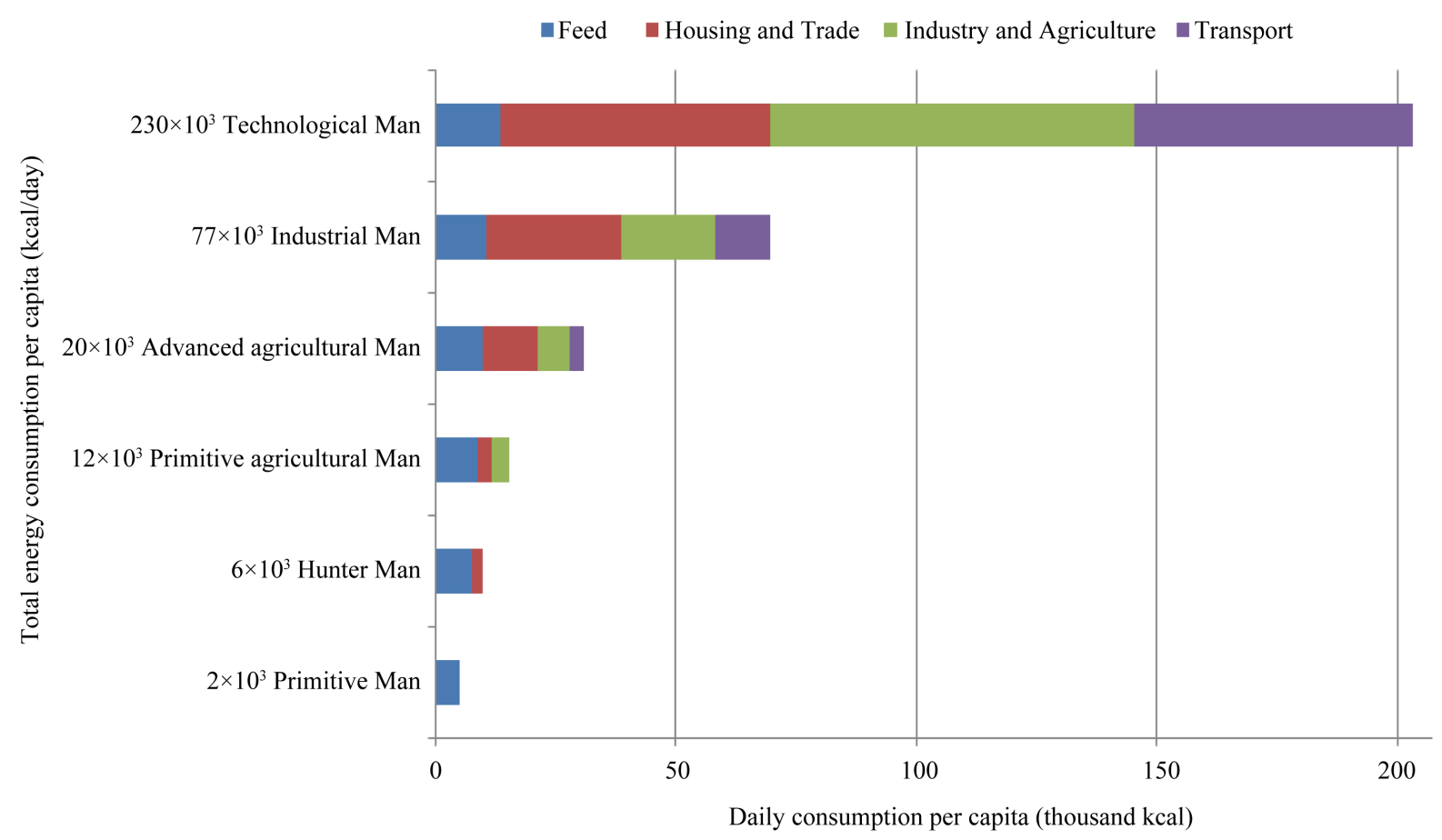

Figure 1. Evolution of human energy consumption troughout history (based on [6]). 
nomic development of a society, but also the catalyst of this same development.

The relationship between energy and development is evidenced in Table 1 and Table 2 .

Indeed, by analyzing countries' data, related to GDP and energy consumption, we notice that countries that have higher energy consumption tend to be those with higher GDP. Of the 10 countries with the highest GDP in the world, only Italy and the UK do not appear among the 10 largest energy consumers-showing the relationship between economic development and energy consumption.

However, this relation between GDP and energy consumption, measured by calculating energy intensitywhere it calculates the energy required to produce one unit of GDP (in Dollar case) — has been changing in recent times. Thus, OECD countries show a GDP growth without corresponding to a proportional increase in energy consumption, reducing their energy intensities. According to the World Energy Council (2004), this phenomenon is due to energy efficiency policies adopted in these countries, as well as changes in their economic structures or the energy matrices [2].

On the other hand, for non-OECD countries energy demand has increased considerably as a consequence of population, economic, urban and industrial growth. According to studies by the IEA (2010) [1], between the years 2008 and 2035 energy consumption in non-OECD countries is expected to increase 64\%, while in OECD the growth is only $3 \%$. Thus, it is expected that the share of developed countries in world energy consumption countries, which declined from $61 \%$ in 1973 to $44 \%$ in 2008, decrease to only $33 \%$ in 2035 .

The same studies show that the OECD countries have, on average, an annual growth of primary energy demand of $0.1 \%$ (and in some cases, like Japan, rates are negative), while China and India have an annual increase of over $2.0 \%$. These two countries are those that contribute most to the increase in global energy consumption. According to the IEA studies, the increase in primary energy demand in China in the period 2008-2035 is expected to be $75 \%$, corresponding to $36 \%$ of global growth and resulting, therefore, in $22 \%$ of the total demand

\begin{tabular}{|cc|}
\hline Table 1. Ranking of the energy comsumption by countries (2011) [4]. \\
\hline Country & Consumption (mtoe) \\
\hline $1^{\circ}$ China & 2648 \\
$2^{\circ}$ USA & 2225 \\
$3^{\circ}$ India & 759 \\
$4^{\circ}$ Russia & 725 \\
$5^{\circ}$ Japan & 469 \\
$6^{\circ}$ Germany & 317 \\
$7^{\circ}$ Brazil & 268 \\
$8^{\circ}$ Canada & 266 \\
$9^{\circ}$ South Korea & 257 \\
$10^{\circ}$ France & 257 \\
\hline
\end{tabular}

\begin{tabular}{cc}
\hline Table 2. Ranking of global GDP (2011) [3]. \\
\hline Country & GDP (millions USD) \\
\hline $1^{\circ}$ USA & 2648 \\
$2^{\circ}$ China & 2225 \\
$3^{\circ}$ Japan & 759 \\
$4^{\circ}$ Germany & 725 \\
$5^{\circ}$ France & 469 \\
$6^{\circ}$ Brazil & 317 \\
$7^{\circ}$ United Kingdom & 268 \\
$8^{\circ}$ Italy & 266 \\
$9^{\circ}$ Russia & 257 \\
$10^{\circ}$ Canada & 257 \\
\hline
\end{tabular}


on the planet. India is the second largest contributor to the increase of energy consumption, accounting for $18 \%$ of it and having the highest annual growth rate (over 3.0\%). Not coincidentally, these two countries are those whose studies point to have the highest rates of growth of GDP (forecast $5.7 \%$ and $6.4 \%$, respectively). Brazil is expected to be the third country in the world regarding the growth rates of GDP and energy demand in the period 2008-2035 settling with one of the largest economies in the world and configured as one of the largest energy consumers in the world.

Still, besides being associated with the issue of economic development, we must not forget the social function involving energy production, since the primary purpose of energy services is to meet the needs of human beings, which means production and consumption, means to achieve it [8]. Thus, countries with higher HDI (Human Development Index) tend to be those with higher energy consumption [9], with an income factor that most influences this consumption (among the indicators that make up the HDI) [6]. Still, it must be emphasized that the low power consumption is not the only cause of poverty and development, however, a good indicator of its causes—as, for example, low levels of education and poor health systems.

Once established the relationship between energy and human development, it is important to highlight that the use of energy, by being associated with the technical development and the appropriation of space, notably affects the spatial configuration and, therefore, the environment, resulting in socio-cultural changes and significant demographic. Thus, projects involving energy production should be considered in all stages of the production chain, the social impacts of these types of development [9]. Otherwise, it will be creating a great contradiction, since above all, energy production is primarily intended to provide the satisfaction of human needs.

\section{Essentials of Energy Integration}

In the current context of increasing demand for natural resources, and the prospect of depletion of many of these, energy planning becomes very important and includes the research and development of alternative sources of energy production technologies that are associated with renewable resources and causing an environmental impact and minimum share.

As noted in the introduction, the energy planning involves access to energy resources. Due to the fact that they are unevenly distributed across the planet, access to them is the subject of disputes filed by various interests, being a matter of great geopolitical importance to a state.

Discussing the dependence of developed for natural resources located in other regions of the world, Hobsbawm (2007) [10] points out that one of the motivations of European imperialism over other regions of the world, occurred between the years 1875 and 1914 was the technological development that generated the need for "raw materials, due to weather or geological chance would be found exclusively or deep in remote places" (p. 96) supply. In many cases, even having plenty of resources in their territories, developed countries seek to exploit them in other regions. A clear example would be the American experience with oil after the Second World War, when the country encouraged their companies to exploit the oil fields of the Middle East, preserving located in its territory, economic, national security strategy [11]. Harvey (2011) [12] discusses the US interests in the Middle East associating with the fact that the region has the largest oil reserves in the world. Thus, by controlling the region, the United States also controls the access to this feature and with it, the global oil Market [12].

Several other authors discuss the relationship between energy security and military action in countries outside their national territories. Triola (2008) [13], an employee of the US Navy, maintains Harvey's assertions (2011) by arguing that the energy supply of the United States is a matter of national security and, therefore, also involves military interests. Nagy (2009) [14], in turn, suggests the militarization of energy security as a responsibility of the Organization of the North Atlantic Treaty (NATO), leaving her secure supply of energy resources.

These kinds of assertions show us that the access to energy resources involves different kinds of interests between countries that can be conflicting. Thus, as a reasonable alternative, it is considered that policies aimed at energy integration can meet harmoniously interests involved. The central idea of the energy integration is noted the contribution that economic and energy sectors in each country can the social and economic development process within the framework of regional integration [9] [15]. By enabling the commercialization of energy resources, or electricity itself, based on multilateral agreements, energy integration can provide a more reliable and efficient supply to large consumers of energy, also bringing economic gains for countries that sell their energy resources and its surplus electricity. In the long term, is optimized energy production, while taking advantage of the diversity resulting from connection to energy sources from neighboring countries, eliminating the dependence on a single source of energy and reducing supply costs. Also, the creation of economic blocs and 
energy strengthens the integrated region, leveraging the commercial, political, social and cultural relations between its members.

Moreover, despite the potential benefits related to cross-border energy integration, there are many elements that hinder their achievement, they order being political, technical, economic and environmental.

One of the main difficulties associated with the implementation of integration projects refers to the articulation of rules and congruent with the stimulus to investment and energy interdependence policies. It involves a number of agreements, targets and regulations that involve complex legal issues facing opening markets and thereby enabling the creation of rules to facilitate transactions and equity investments (state, private and national is required private multinational). This process involves the countries internal political issues-related to the approval and acceptance of laws and internal projects involving diverse interests within the nation—as well as elements associated with the foreign policy of each state and its geopolitical interests in the region.

With regard to differences of interests among countries in the South American case, one can use the question as an example of Bolivian gas, in which Bolivia nationalized refineries belonging to Petrobras, claiming that the contracts had been established the wounded interests of the Bolivian nation. Another example relates to historical differences between Chile and Bolivia, involving Bolivia access to the Pacific Ocean as a barrier to agreements between the two countries [16].

Obviously, the larger the number of agents involved in the process, the greater the difficulty in establishing policies of interest to everyone. That's why the most successful experiments were those made them bilaterally arising from projects with strong participation of national states.

From a technical standpoint, the interconnections require an infrastructure with bi-reaching goals—or multithat includes the participation of all involved and interested. So that the integration process is done in a cohesive manner, it is essential to studies that provide adequate planning be made-with regard to the generation, transmission and distribution of energy as well as the interests and economic returns for the various agents involved in the issue. The greater the need for infrastructure and technical complexity related to the projects become more expensive the same-which implies the need for large investments of money (and, most often, in various financing). In the case of South America, for example, infrastructure integration projects to sizable proportions by both distances, as the natural difficulties imposed by the environment.

\section{Resourcefulness along the World of Energy Integration}

\section{A) European Union}

Throughout the twentieth century a number of policy initiatives and energy integration have been deployed worldwide, the most successful being developed within the European Union-that is, in a larger context of economic and political integration. Unlike what happened historically in most cases, the European experience has been guided by multilateralism and the creation of supranational regulators.

The first step in this process occurred in 1951, with the signing of the ECSC Treaty, which established the creation of the European Coal and Steel in a context in which the countries of the continent sought to economically rebuild the region after the Second World War. With this treaty, signed by France, Germany, Italy, Netherlands, Belgium and Luxembourg, we sought to integrate the Franco-German production of coal and steelraw materials essential to industrial activity and the local economy at the time- through the creation of a common market aimed at economic development, job creation and improved quality of life.

In 1957, were signed the Treaties of Rome establishing the European Economic Community (EEC) and the European Atomic Energy Community (Euratom), establishing the creation of a common market on the continent and recognizing the importance and need to develop common energy policies the member countries in the context of regional economic and social development. To overcome the uncertainties related to traditional energy sources, the Member States of Euratom sought on nuclear energy a means to ensure energy security and independence. Thus, according to documents of the European Union itself (2013), "as the cost of investing in energy beyond the means of individual States, the founding members joined together to form the Euratom".

Throughout the following decades, the process of integration into the European continent was deepening, also encompassing the energy sector-seen as crucial to regional socioeconomic development. The main frame of this integration initiative came in 1992 with the Maastricht Treaty, which created the European Union and in which it commits to the creation and development of trans-European networks in the sectors of transport infrastructure, telecommunications and energy. Thus, it is for the authority to "promote the interconnection and interoperability of national networks as well as access to such networks" through the actions of its supranational po- 
litical bodies [17].

From the descriptions above, it can be seen that the integration of the energy sector is part of European policies since the mid-twentieth century, are subordinate, in turn, to the initiatives of economic and political integration - and therefore cannot be analyzed outside this context. Similarly, we note that, over time, these policies are no longer focused on specific energy sources (coal and nuclear), for, after the Maastricht Treaty, extended to the whole European energy system and further increase use of sources clean and renewable energy-increasingly promoted by the European Union's energy policy, with the aim of reducing emissions of greenhouse gases on the continent-and also the integration into the natural gas supply.

The strategy of integration of renewable sources resulted in a less centralized and diversified system, strengthening the European integrated network. The Policy of 2009 set by the European Parliament and the Council of the European Union, concerning common rules for the internal European market and the unequal terms of trade of electricity between the member states must be overcome by the right of free choice suppliers reassured consumers.

The transmission of electricity on the continent is through the ENTSO-E network, established in July 2009, according to Policy 2009 and composed of 42 operators in 34 countries, with $305.000 \mathrm{~km}$ of transmission and $828 \mathrm{GW}$ of generation, to supply and demand of $3400 \mathrm{TWh} /$ year, serving more than 525 million citizens. The purpose of this initiative was to integrate the different operators of the system to European legislation, promoting development through reliable operation, technical and administrative support, and security in meeting the demand of the system. In this context, the intelligent transmission networks (smart grids) send electricity from points of generation to consumers using a monitoring system with digital technology, allowing the integrated use of decentralized energy sources—like solar and wind—by assimilating its entry in periods of wind and sun.

Naturally, the process of integration of the European energy sector also faces obstacles, but in the context of this work concerns us understand how is the process of multilateralism and integration with respect to interconnections and to political and economic technical aspects involved—so compared with other experiences around the world.

\section{B) Africa}

Apart from the European experience, energy integration initiatives were implemented in other continents, so that, in most cases, they gave bilaterally and were much less extensive than in the European Union.

In Sub-Saharan Africa, for example, the first cross-border electricity interconnections were deployed around large hydroelectric projects. The first interconnection was built in 1958, with the transmission line of $132 \mathrm{kV}$ connecting the hydroelectric plant of Owens Falls, in Uganda, the capital of Kenya (Nairobi). Built in the Democratic Republic of Congo and interconnected with neighboring countries such as Zambia, Congo and otherslater binational hydroelectric, as the Kariba North (on the border between Zambia and Zimbabwe) and the development of the Inga hydroelectric complex fall were built the southern region of the continent [18]. Parts of such linkages were incorporated into the Southern African Power Pool (SAAP), one regional system operating on the continent until 2008, when it began operating the West African Power Pool. A Power Pool is an interconnected system obtained by joining two or more interconnected electric systems-managed as if it were a system - by reallocating the demand and supply of energy and generation capacity, in order to operate more efficiently and secure.

The SAPP was created in August 1995 as an association of electric power enterprises vertically integrated, representing the 12 nations of the Commonwealth of the Southern African Development Community (SADC, for its acronym in English): Angola, Botswana, DRC, Lesotho, Malawi, Mozambique, Namibia, South Africa, Swaziland, Tanzania, Zambia and Zimbabwe [19].

\section{C) North America}

Energy integration of North America shall be considered in the context of the Free Trade Agreement (NAFTA) an agenda of neoliberal policies designed to achieve deeper levels of regulatory, institutional and policy integration that enable the integration of markets the continent [20]. But despite NAFTA establish a "trilateral landmark" for trade in energy and electricity [21] features the experiences of energy integration in the region are, paradoxically, based on bilateral relations, in which the United States appear as large buyer power and energy resources (such as oil and natural gas) from Mexico, and especially in Canada—energy trade between Mexico and Canada is almost non-existent [22].

In fact, 99\% of all Canadian energy exports are destined for the United States [23], indicating the absence of trade in energy resources and electricity from Canada to Mexico. Even Mexico is a major oil supplier to the 
United States, its energy market is poorly integrated into the US (compared to Canada)—due to political and economic and internal [22] issues.

With respect to the electric integration, specifically, it is less advanced than in the natural gas and oil industries. Even so, there is a trade of electricity in the region, made possible by interconnections linking the United States to Mexico, and especially in Canada. In this context, the United States are characterized as major importers of electricity, while also exporting (to a lesser extent) to its neighbors.

Finally, it is important to note that there are differing opinions regarding the benefits of the integration process in North America. While Doucet (2007) [22] argues that this process is extremely beneficial for Canada, as the United States are the major buyers, Campbell (2007) [20] believes that these relationships undermine the energy security of the country. To justify his point of view, this author takes as argument the fact that, by the rules of NAFTA, Canada can only reduce its exports of oil and gas to the United States in the same proportion that reduce their production to market internal, with this, the country loses the right to reduce its exports to the US, even aiming to prolong the durability of their internal reserves or reduce its imports. For Campbell (2007), the fact that Mexico to impose certain restrictions on the integration model imposed by the United States represents a defense of local energy security, and is therefore beneficial for the country.

\section{Energy Integration in South America}

\subsection{South American Energetic Potential}

Because it is a region rich in energy resources, especially oil and water resources, various integration projects in terms of energy already deployed or are in process in South America is worth mentioning that many of these features occur so border (making it complex to manage and operate), highlighting the Andes and the Amazon River.

The Andes is a large mountain range spanning five countries in South America—as well as being a natural border between them - and constitutes a major mineral area in the world: gold, silver, copper, zinc, nickel, iron granite among others. The Amazon River, its waters represent much of the available freshwater in the world. This river originates in Peru, crossing the border with Colombia until you reach the tri-border involving these two countries and Brazil. Not coincidentally, these three countries are those with the potential hydroelectric May in South America, as shown in Figure 2.

By observing the above data, it is seen that the total hydropower potential of the American South is $590 \mathrm{GW}$, so that Brazil is by far the country with the greatest potential, exceeding $250 \mathrm{GW}$. No wonder that this country is one that has the highest hydroelectric power generation on the continent (403 TWh in 2010), corresponding to

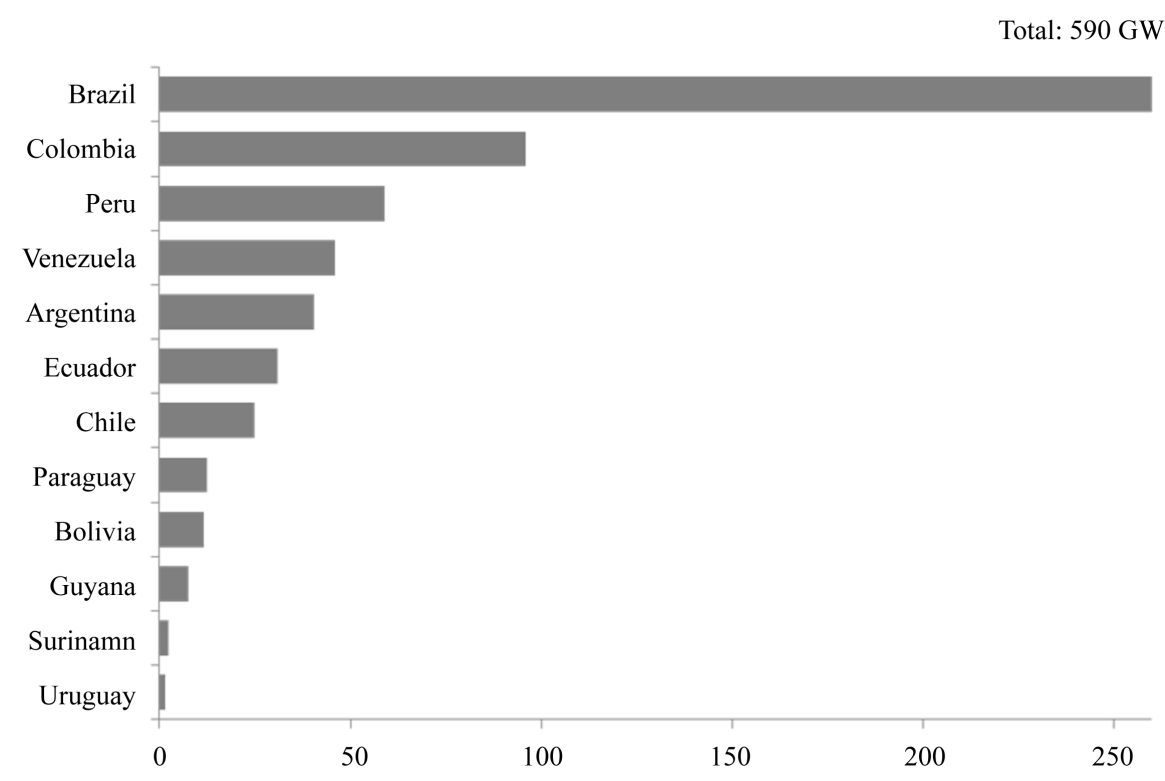

Figure 2. Hydroelectric potential in South America (2010). 
11.5\% of the world's hydroelectric production, according to Table 3. Likewise, it should be highlighted Venezuela, since this country occupies the 9th place ranking producer of hydroelectricity in the world and is the second largest South American producer.

Regarding hydrocarbons should be highlighted reserves of oil and natural gas on the continent. South America has about $4 \%$ of global natural gas reserves, so that the majority is located in Venezuela. Figure 3 shows the distribution of proved reserves of natural gas in the region.

Oil cannot be overlooked when it comes to meeting the South American energy potential. The region has large proven reserves of this resource, highlighting, once again, to Venezuela. According to data from the US Energy Information Administration-an agency linked to the US government-in Venezuelan territory is the second largest proven oil reserves in the world (211.2, billion barrels of oil) smaller only than that of Saudi Arabia. Brazil also deserves mention, being in 15th place in the global ranking of countries with the largest oil reserves. Figure 4 shows that, after Venezuela and Brazil, Ecuador has the third largest proven oil reserves in South America.

\subsection{Regional Integration Process in South America}

The process of South American energy integration starts from the mid-twentieth century, by means of natural gas, having two axes of the main action, oriented from the actions of the CAN (Andean Community of Nations)

Table 3. The biggest hydroelectricity producers in the world (IEA, 2010).

\begin{tabular}{ccc}
\hline Producers & TWh & $\begin{array}{c}\text { \% of the global installed } \\
\text { capacity }\end{array}$ \\
\hline China & 722 & 20.5 \\
Brazil & 403 & 11.5 \\
Canada & 352 & 10 \\
United States & 286 & 8.1 \\
Russia & 168 & 4.8 \\
Norway & 118 & 3.4 \\
India & 114 & 3.3 \\
Japan & 91 & 2.6 \\
Venezuela & 77 & 2.2 \\
France & 67 & 1.9 \\
Other Countries & 1118 & 31.7 \\
World & $\mathbf{3 5 1 6}$ & $\mathbf{1 0 0}$ \\
\hline
\end{tabular}

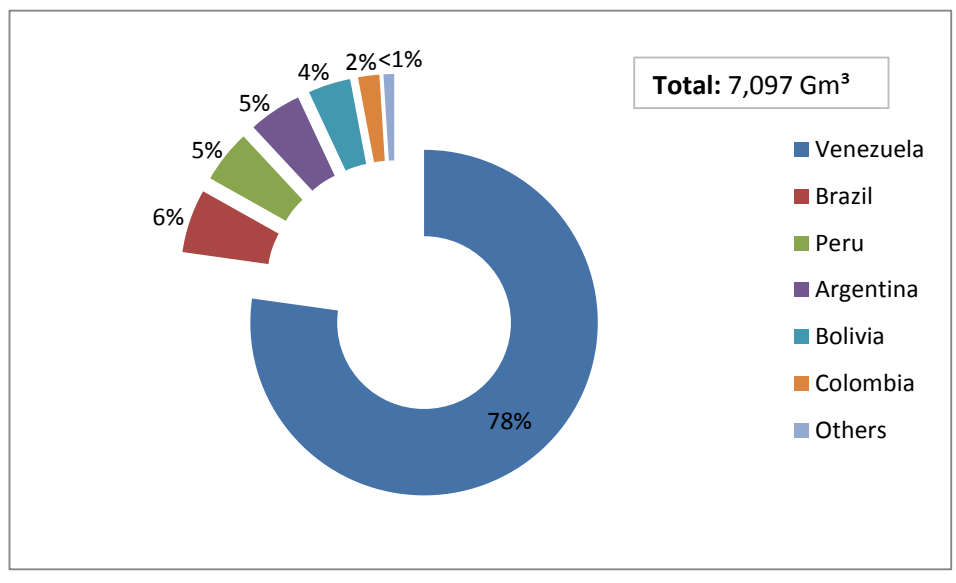

Figure 3. Regional distribution of proved reserves of natural gas in South America in 2010. 


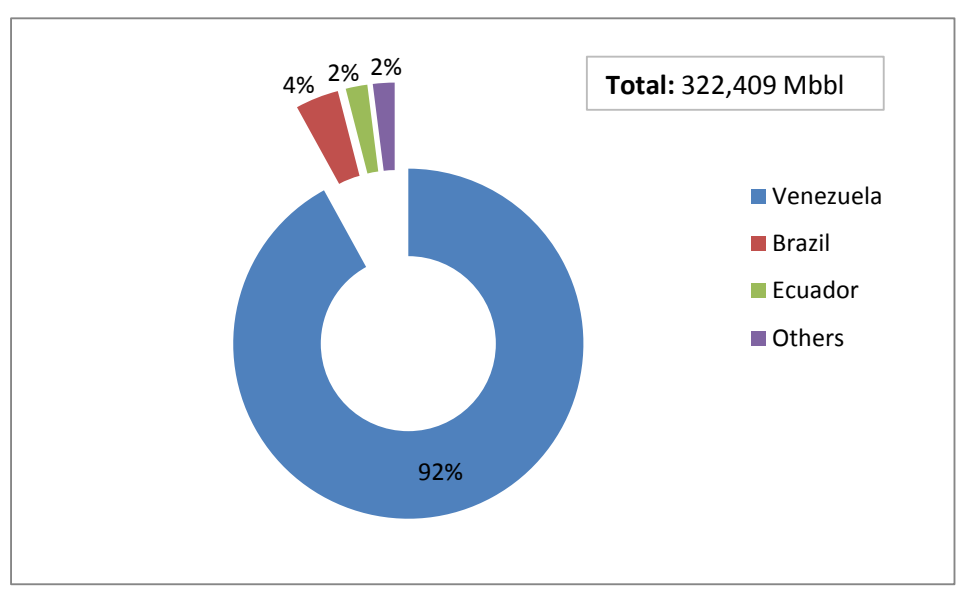

Figure 4. Distribution of proved oil reserves in South America (2010) ${ }^{1}$.

and Mercosur [7]. It should be noted that these economic blocks have economic complementation agreements among themselves and with Chile-a country that is not a member of both.

The process of energy integration occurred in the twentieth century can be divided into two stages.

The first, between the early 1970s and the late 1980s, was marked by a great performance of National States in building binational projects. These must be highlighted, the Bolivia - Argentina, hydroelectric plants Salto Grande (Argentina and Uruguay), Itaipu (Brazil/Paraguay) and Yacyretá (Paraguay/Argentina), and transmission lines associated with these binational plants.

The period that occurred after the end of the 1980s was marked by economic and political reforms in neoliberal, resulting in decreased performance of states and the increased private participation in the South American country's economy. Thus, has begun the implementation of projects with varying degrees of participation of private, mixed and public enterprises - involving mainly the hydrocarbons sector. In this period many binational pipelines were constructed, demonstrating the importance of this resource within the energy integration projects in South America ${ }^{2}$.

Despite the differences involving the form of state action, it is noticed that, in both periods mentioned above, projects were restricted to the bilateral framework, demonstrating the absence of a regional integration policy indeed.

The political and economic changes on the continent, in the 21th century turned, once again, the landscape of energy integration in the region. First, the election of heads of state of the Left parties made to gather strength in the region's anti-neoliberal and anti-imperialist discourse, changing the logic of financing projects in the region and strengthening the participation of States in the economies of the countries again. Meanwhile, economic growth achieved by regional countries, especially Brazil, resulted in increased energy demand of us. With this, the first decade of this century, there was a tendency to turn that vision bilaterally in order to give a more regionalist and multilateral integration projects to character. It was in this context that was created in 2000, the Initiative for the Integration of Regional Infrastructure in South America (IIRSA), in order to promote the interconnection of transport, telecommunications, energy, oil and gas pipelines.

With the construction of infrastructure related to IIRSA project, and with funding from financial institutions such as the Inter-American Development Bank (IDB), the World Bank, the Andean Development Corporation (CAF) and the Financial Fund for the Development of PrataBasin (FONPLATA), was intended to establish conditions conducive to the development of trade agreements and energy integration. Thus was deposited much confidence in the success of IIRSA, despite the logical difficulties inherent to their success—-such as: history of binational conflicts; disparity markets; privilege certain actors, and difficulty of regulatory consistency between countries [9]. But in 2009, IIRSA has been discontinued and its projects were linked to the South American Council of Infrastructure and Planning (COSIPLAN) - linked to the Union of South American Nations (UNASUR). Also, COSIPLAN along with UNASUR, retains the idea of strengthening multilateral relations in South

\footnotetext{
${ }^{1}$ Source: Based on OLADE.

${ }^{2}$ In fact, natural gas is one of the vectors of energy integration on the continent, representing most of the energy matrix of some South American countries such as Argentina, Bolivia and Chile.
} 
America, in order to give greater political support infrastructure integration projects.

The following is a brief discussion of the process of energy integration in South America, with a focus on initiatives both within the economic bloc (Mercosur and CAN), and outside them.

\section{A) Mercosur Region}

Mercosur is an economic bloc, created in 1991, consisting of Brazil, Argentina, Paraguay, Uruguay and Venezuela, whose members Bolivia, Chile, Ecuador, Colombia and Peru.

Despite the creation of this economic bloc be linked to the need for expansion of domestic markets and stimulate the circulation of goods and services in the region — without being tied directly to the energy issue - the binational relations among member countries prior to its creation. Since the creation of Mercosur, the energy sector of member countries showed considerable changes. Among them stand out the reform of the role of the state (acting more as a regulator than as an entrepreneur ) and consolidation of natural gas as an integrating feature of the region - as all countries in the region have construction projects in the pipeline [9].

Among the transnational projects of power generation worth mentioning the construction of Itaipu, Salto Grande and Yacyretá (already mentioned above) plants, besides the Central Salta—a combined cycle power station, built by a Chilean company to generate electricity from gas natural from Argentina, but without providing energy for this country. We cannot forget that Chile is considered a poor country in terms of ownership of energy resources.

In the case of Itaipu (binational venture involving Brazil and Paraguay, aiming harness the hydroelectric potential of the Paraná River), Brazil was responsible for the setup project and investments for the construction of the plant—in addition to financing the part that would fit Paraguay [7]. In 2008, the plant secured supply 87.3\% of all electricity consumed in Paraguay and $19.3 \%$ of the demand of the Brazilian Interconnected System. Importantly, Paraguay does not consume all of your energy generated, since it takes only $20 \%$ of what is produced to meet its domestic demand for energy, causing the remaining $80 \%$ are sold to Brazil.

\section{B) Andean Community of Nations Region}

The Andean Community of Nations (CAN) is formed by Peru, Bolivia, Ecuador and Colombia. In the past, Chile and Venezuela also integrated organization but abandoned (at different times) for political and economic mismatches. The region covered by the CAN has a great potential energy - both in terms of hydrocarbons (oil and gas) as regards the hydro, among others. With regard to the oil market, Venezuela, Colombia and Ecuador are configured as suppliers to countries like Brazil, Chile and Peru-since they have oil consumption that exceeds their production, in contrast with Bolivia and Venezuela that have resources that exceed their local demands. You need to highlight the situation of Chile, due to its lack of energy resources, is much interested in integration projects that enable the supply of its domestic energy demand.

According to Castro, Dassie and Delgado (2009) [24], the process of energy integration in the Andean region began in 1969 with the construction of the transmission line Zulia - La Fria, connecting Colombia and Venezuela. Although the energy exchange was not significant due to what they call security problems in the power supply, the authors argue that this project was the first step for the energy integration occurred in the region. The same authors state that the evolution of the process of electrical interconnection between the Andean countries has enabled advances, such as the prediction of building an interconnection between Bolivia and SIEPAC. Udaeta, Burani, Fagá and Oliva (2006) [9] also highlight the role of interconnections in the integration process in CAN, noting that Bolivia appears as a "hinge", because of its possibilities of interconnection with Brazil, Chile, Argentina and Peru.

Besides the physical integration, one cannot ignore the advances that have occurred in political and legal terms to enable the marketing and access to transmission networks between countries. Thanks to that, better expectations around integration projects in the region. Even so, it is of great political, economic and technical complexity to implementation of transnational projects—so that the more countries involved, and the larger the area covered, the greater the difficulty. Antunes (2007) [16] cites the proposal for energy integration taken by Chile in 2007, and that would involve this country along with Bolivia, Ecuador, Peru and Colombia, based on an Andean multilateral agreement aimed at "prevent interference geopolitical discussions on exit to the sea for Bolivia lost”(p. 5).

\section{C) Other Energetic Integration Projects in South America}

Obviously, one cannot reduce the process energy integration in South America only to economic blocs in the region. In this sense, the creation of IIRSA, and later the COSIPLAN makes integration projects that go beyond the limits of economic blocs, giving greater geopolitical cohesion to the region are encouraged. In the case of 
IIRSA, a portfolio of projects divided into eight sub-regions was taken, clearly transcending the boundaries of economic blocs: the Hub; Capricorn Hub, Amazon Hub; Guianese Shield Hub, Southern Hub, Central Interoceanic Hub; MERCOSUR-Chile, Brazil and Peru-Bolivia.

Throughout its existence, the IIRSA delivered 524 projects, of which 451 (about 86\%) belonging to the transport sector and whose investments were received from more than 55 billion dollars. The energy sector received 64 designs, but although they represent $12 \%$ of the total, his works surpassed the cost of 44 billion dollars (about $42 \%$ of the investment portfolio of IIRSA), due to the complexity and magnitude of the projects. Have the communications sector received only 9 projects, which together cost less than $\$ 50$ million [25]. By analyzing these data, it is clear that the IIRSA projects favored the transport sector, to the detriment of integration of energy and communication sectors. Thus, we can say that IIRSA fostered a process that is configured much like physical interconnection, than actual integration [26]. This phenomenon is mainly related to building a road network connecting the Pacific and Atlantic interests, in order to facilitate the flow of goods across the continent.

IIRSA-related projects are targets for some criticism. Despite advances in regard to strengthening networks of transport, energy and communication sectors were left in the background. Gudynas [26] questions the interests that were behind the IIRSA project by privileging the physical interconnections (such as roads, waterways and pipelines), and seek not intrinsic to strengthen other aspects integration process-as political, productive and cultural ties. Other limitations are related to IIRSA the lack of progress in the harmonization of sectorial policies and relevant regulations and little consideration given to social and environmental aspects.

As regards the pursuit of multilateralism in the South American integration process, it should be noted the role of Bolivia, which has a role of coordination between the countries of the Southern Cone and the Andean Community. Being a country with large reserves of natural gas and has low power consumption; Bolivia is shaping up as a major supplier of this resource to countries that need to import it-like Chile and Brazil. You can use the example of the Bolivia-Brazil pipeline, named by the authors as a major milestone of the energy integration in South America, the importance of consolidating gas sector in the Brazilian energy matrix.

Energy integration also consolidates Brazil as a major buyer of energy, since, despite having large reserves of energy resources, the country has shown a significant increase in its demand. Therefore, the Brazilian government has increasingly sought to stimulate energy ventures outside its territory. However, in addition to seeking to satisfy its energy demand, there is a clear interest in encouraging the participation of Brazilian capital on projects through funding from its National Bank for Economic and Social Development (BNDES) and the participation of Brazilian construction companies civil.

In this context, the process of energy integration between Brazil and Peru should be highlighted. In 2009, was signed by both countries an agreement for the construction of six hydroelectric plants geared to supply the energy markets of both countries and located in the Amazon basin of Peru's territory. Due to the location where it will be deployed, covering areas of high biodiversity and where local communities, projects of this nature are carried live by controversy due to contradictions involving their economic gains and environmental impacts they generate. In fact, despite these initiatives have targeted to meet economic interests in the region, their social and environmental impacts are left in the background.

\section{Some Conclusions Related Endogenous Energy-Integration}

Despite the difficulties involving energy integration (as questions of sovereignty of countries and divergence of interests among stakeholders-be they citizens, companies, nation states or other agents), the process of energy integration can bring a lot of benefits for developing countries, since the production and consumption of energy are factors that directly influence the economic development process. Likewise, energy resources are not distributed evenly around the planet, so that trade in energy resources and electricity can benefit both the importing country and the exporting-depending on the way the procedure is conducted and interests involved.

Second, one cannot forget that the energy integration policies should be analyzed in a broader context of economic integration. Without economic integration in fact, the process of energy integration weakens or worse it become unviable, since it depends on complex and coherent political, legal and economic foundations established by supranational institutions respected by all. Often, historical political conflicts between countries are an obstacle to the process of economic and political integration, undermining thereby the energy integration. The South American case shows that, a context in which the process of economic integration is a little-advanced 
stage makes energy integration slow down.

By analyzing the process of historical energy integration in South America, it appears that this has gone through several changes over the past decades-following the political and economic changes occurring in the continent. In the 21th century, for example, strengthening the anti-imperialist and anti-neoliberal discourse has resulted in increased participation of states and their companies in making decisions and profits relating to the exploitation of energy resources, and reducing reliance on funding coming from the IDB and the World Bankthat guided the economic policies in the region. Also, the economic growth of countries resulted in an increase in their energy demands, requiring new developments in the energy sector. It should be noted Brazil, which has been consolidated as a lead in this process — stimulating new projects and the participation of the Brazilian capital, through BNDES financing and the involvement of construction companies-due to their economic powerand thereby politician in the region_as well as their energy requirements, which have been increasing in recent times.

Comment is also likely the fact that transnational energy projects are restricted, mostly, to bilaterally. This shows that the process of energy integration in South America was not an end in itself, but a means to meet the energy and economic needs of certain countries and agents in certain recent historical periods. In other words, projects like Itaipu and Bolivia Brazil Gas Pipeline had main objective to serve the economic interests of the parties involved-and not energy integration itself. Even in more recent initiatives, such as IIRSA, the integration of the energy sectors of the South American countries occurs in a larger plan: the integration of infrastructure (which also involves networks of movement and communication) - is therefore a means to achieve greater integration project. Even so, IIRSA - and now COSIPLAN—is the main initiative of energy integration in South America in the beginning of the 21th century, in a context where projects happen beyond the traditional economic blocs.

Moreover, the integration process is not limited to the creation of physical links in a region. It requires a series of policies and regulations to facilitate harmonic different types of flows inherent in this process as well as the narrowing of political, productive and cultural ties. In this sense, the results were still unsatisfactory, since we focused on the transportation industry related projects, at the expense of others-that cater to specific economic interests, but they do not contribute to reducing social and economic inequalities present within the southern countries Americans, and the continent in general. So far it needs to advance in South America-if we want a restricted integration only to facilitating the flow of goods across the continent

Finally, the various changes occurring in the energy integration process in the region show a lack of consensus in defining a comprehensive model of integration and satisfying interests of all States and involved actors in the region. Something that is directly related to existing internal asymmetries within countries, but also is between them. Thus, for this to be overcome, it is necessary that these asymmetries are resolved both within countries and between them.

\section{References}

[1] Agência Internacional de Energia (IEA) (2010) World Energy Outlook 2010. Paris.

[2] World Energy Council (WEC) - Comitê Brasileiro (2004) Eficiência Energética: Uma análise mundial. Rio de Janeiro. Disponível no www.worldenergy.org

[3] Fundo Monetário Internacional (FMI) (2012) Dados disponíveis no www.imf.org

[4] ENERDATA (2012) Dados disponíveis no www.enerdata.net

[5] Cipolla, C.M. (1961) Sources d’énergieethistoire de l’humanité. In: Annales. Économies, Sociétés, Civilisations. 16e année, N. 3, 521-534.

[6] Goldemberg, J. and Lucon, O. (2008) Energia, Meio Ambiente e Desenvolvimento. São Paulo, Edusp.

[7] D’ÁVALOS, Victorio Enrique Oxília. Raízes Socioeconômicas da Integração Energética na América do Sul: análise dos projetos Itaipu Binacional, Gasbol e Gasandes. Tese de Doutorado. PPGE-USP. São Paulo, 2009.

[8] Udaeta, M.E.M. (1997) Planejamento Integrado de Recursos Energéticos para o Setor Elétrico—PIR (Pensando o Desenvolvimento Sustentável). Epusp, tese de doutorado, São Paulo.

[9] Udaeta, M.E.M., Burani, G.F., Fagá, M.T.W. and Oliva, C.R.R. (2006) Ponderação analítica para da integração energética na América do Sul. Revista Brasileira de Energia, 12.

[10] Hobsbawm, E. (2007) A era dos impérios 1875-1914. Ed. Paz e Terra, São Paulo. 
[11] Scarlato, F.C. (2008) O Espaço Industrial Brasileiro: Sociedade, Industrialização e Regionalização do Brasil. In: Ross, J.L.S., Org., Geografia do Brasil, 5th edição, Edusp, São Paulo.

[12] Harvey, D. (2011) O novo imperialismo. Edições Loyola, São Paulo.

[13] Triola, L.C. (2008) Energy and National Security: An Exploration of Threats, Solutions and Alternative Futures. IEEE Energy 2030, Atlanta, 17-18 November 2008, 13-35.

[14] Nagy, K. (2009) The Additional Benefits of Setting up an Energy Security Centre. Energy, 34, 1715-1720.

[15] Suárez, L.P.L. (2006) O Papel das Petrolíferas para o Desenvolvimento da Integração Energética: A formação do Mercado de Gás Natural na América do Sul. Unicamp, dissertação de mestrado, Campinas.

[16] Antunes, J.C.A. (2007) Infraestrutura na América do Sul: Situação atual, necessidades e complementaridades possíveis com o Brasil. Comissão Econômica para a América Latina e o Caribe (CEPAL).

[17] Tratado De Maastricht. União Europeia, 1992.

[18] WEC-World Energy Council (2005) Regional Energy Integration in Africa. Londres.

[19] Southern African Power Pool (SAAP), 2013. http://www.sapp.co.zw/

[20] Campbell, B. (2007) Una perspectiva nacional de la integración continental del sector canadiense del petróleo y el gás. In: Vargas, R. and Ugalde, J.L.V., Org., Dos modelos de Integración Energética-América del Norte/América del Sur, CISAN, Ciudad de Mexico.

[21] Márquez, D. (2007) El TLCAN plus: La homologación de estándares y sus implicaciones legales para México. In: Vargas, R. and Ugalde, J.L.V., Org., Dos modelos de Integración Energética-América del Norte/América del Sur, CISAN, Ciudad de Mexico.

[22] Doucet, J. (2007) La integración energética norteamericana. Una perspectiva canadiense. In: Vargas, R. and Ugalde, J.L.V., Org., Dos modelos de Integración Energética-América del Norte/América del Sur, CISAN, Ciudad de Mexico.

[23] Us Energy Information Administration, 2012. http://www.eia.gov/countries/analysisbriefs/Canada/canada.pdf

[24] Castro, N.J., Dassie, A.M. and Delgado, D. (2009) Indicadores Mundiais do Setor Elétrico-As Experiências LatinoAmericanas de Integração Energética. GESEL/UFRJ, Rio de Janeiro.

[25] IIRSA (2010) IIRSA diez años después: Sus logros y desafíos. BID-INTAL, Buenos Aires.

[26] Gudynas, E. (2008) As instituições financeiras e a integração na América do Sul. In: Verdum, R., Org., Financiamento e megaprojetos: Uma interpretação da dinâmica regional Sul-Americana, Inesc, Brasília. 